NIHON REOROJĪ GAKKAISHI Vol. 25, No. 4, 193 194 (1997)

(C)1997 The Society of Rheology, Japan.

\title{
論文
}

\section{Deformation Behavior of Extruded Blown Film of High Density Polyethylene}

\author{
Syozo Murakami ${ }^{* 1}$, Kaoru Shimamura ${ }^{* 2}$ and Shinzo Kohjiya ${ }^{* 1}$ \\ * 1 Institute for Chemical Research, Kyoto University, Uji Kyoto-fu 611 \\ *2 Faculty of Engineering, Okayama University, Tushima Okayama 700
}

Extruded blown films of high density polyethylene contain oriented crystalline lamella normal to the extrusion direction. In the elongation perpendicular to the extrusion direction (TD) at -110 ${ }^{\circ} \mathrm{C} \sim 40{ }^{\circ} \mathrm{C}$, the stress suddenly dropped when the film arrived at the yield point and the necking propagated steadily under a constant stress value. TD deformation mechanism is explained by unfolding from one part of the lamellae as proposed by Horio and Kobayashi (silk hat model). On the contrary, in the elongation parallel to the extrusion direction (MD), deformation mechanism is complex and we have proposed an unfolding model. In the MD, stress did not drop even after the yield point, and it maintained a constant value. Consequently the film was uniformly elongated by appearance, but followed by a partial necking. From optical and scannig electron microscopic observations, the lamellae were bended, twisted, or rotated by the stress, and the long axes of lamelae ( $b$-axis) were changed to the drawing direction and the film was elongated by unfolding same as TD elongation.

Key Words : High density polyethylene / Stress-strain curve / Optical observation /

Deformation mechanism

\section{高密度ポリエチレンインフレーションフィルムの延伸挙動}

\section{村上 昌三*1 $・$ 島村 薰 ${ }^{* 2} \cdot$ 桷谷 信三*1}

（原稿受理：1997年 6 月 26 日）

\section{1. 緒 $\overline{2}$}

屈曲性及び半屈曲性の結晶性高分子固体の延伸挙動は温度と 延伸方向に大きく影響される．たとえば，高密度ポリエチレン (HD-PE)インフレーション (EB) フィルムは溶融成形物でも結 晶化度が $85 \%$ 以上と高く，高分子鎖が fold して約 $10 \mathrm{~nm}$ の厚 さの比較的揃った板状晶 (ラメラ晶) から成っている.このラ メラ晶は押出し方向に垂直に積重なって配向 (いわゆる $\mathrm{a}$ 軸配 向 )しており，構造的に異方性のため延伸举動は延伸方向によ って異なっている．そこで我々はこの HD-PEの EB フィルム の力学物性を温度と延伸方向を変えて調へ，延伸中での構造変 化との関倸を検討した。

×'京都大学化学研究所 $\bar{T} 611$ 京都府宇治市五ヶ生

${ }^{2}$ 岡山大学工学部 $\bar{T} 700$ 岡山県岡山市津島中 3-1-1

\section{2. 实 験}

高密度ポリエチレン (Sholex6009) EB フィルムの製膜条件は， 樹脂温度 $180^{\circ} \mathrm{C}$, ドラフト比 55.6 ( 吐出速度 $0.45 \mathrm{~cm} / \mathrm{sec}$, 巻取り 速度 $25.0 \mathrm{~cm} / \mathrm{sec}$ ), 厚さ $0.020 \mathrm{~mm}$, 複屈折 $9.02 \times 10^{-3}$ である. このフィルムを押出し方向 $(\mathrm{MD})$ と MDに対して垂直な方向 (TD) に, 長さ $40 \mathrm{~mm}$, 幅 $5 \mathrm{~mm}$ に切出して一定の引張り速度 $5 \mathrm{~mm} / \mathrm{min}$ で測定した.

\section{3. 結果と考察}

Fig.1 は - $196{ }^{\circ} \mathrm{Cから} 90^{\circ} \mathrm{C}$ まで S-S 曲線であるが， MD と TD を比較すると $-196{ }^{\circ} \mathrm{C}$ 除いて, 初期弾性率および降伏点応 力は TDの方が高い。しかし，降伏点を過ぎてネッキング後の 延伸においては，ほぼ等しい応力で一定值で延伸されていく． 


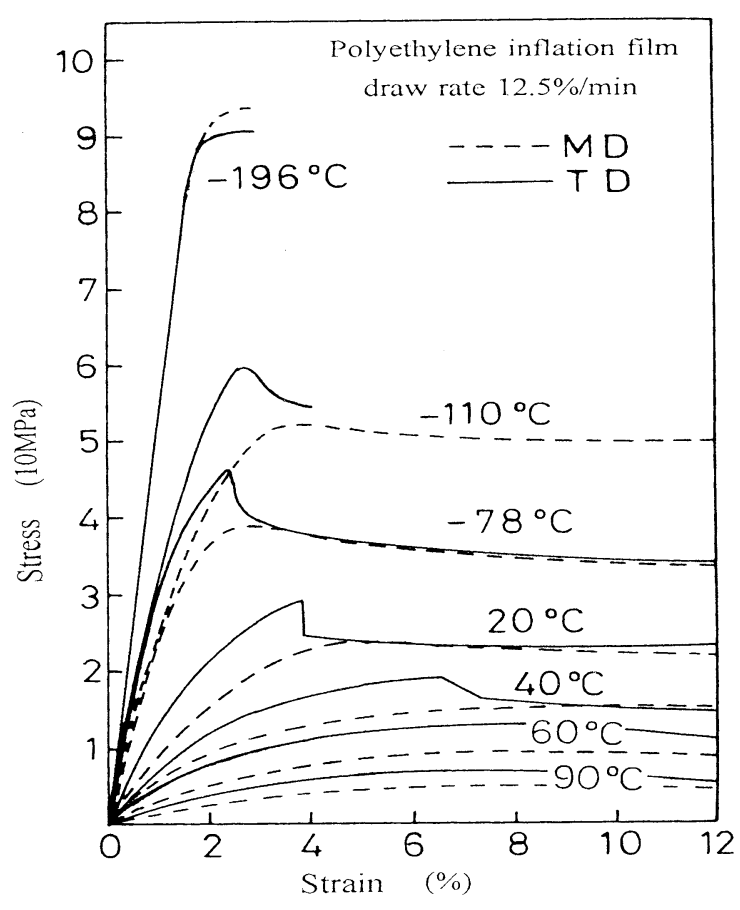

Fig. 1 Dependency of S-S curves on temperature and draming direction.

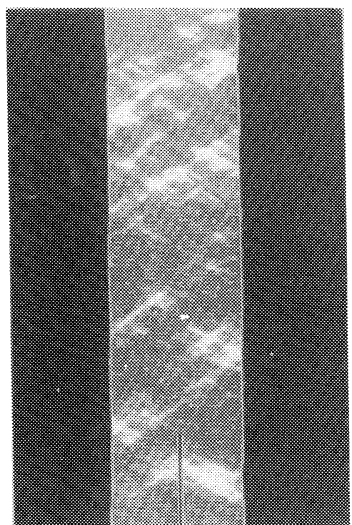

(a) M D

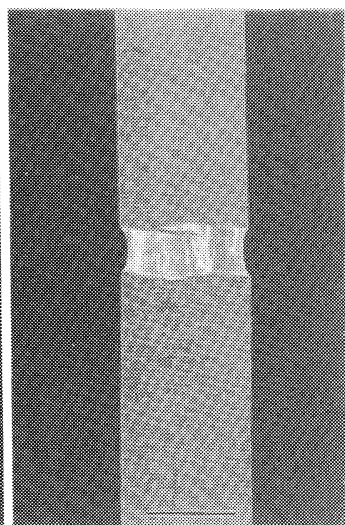

(b)
T D
Fig. 2 Enlarged photographs of necked regions of EB films drawn in $\mathrm{MD}$ and $\mathrm{TD}$ at $20^{\circ} \mathrm{C}$. Dark line shows parallel to $\mathrm{MD}$.

$\mathrm{MD}$ と TDの延伸の大きな違いは $\mathrm{Tg}\left(-110^{\circ} \mathrm{C}\right)$ 以上 $40^{\circ} \mathrm{C}$ までの S-S 曲線の形状にある. 特に $20^{\circ} \mathrm{C}$ の $\mathrm{TD}$ の曲線において, 応 力が降伏点に達した時，急激な応力降下が起こっている。この 降下率江約 15\%にも達している。ここで unfolding によるネッ キングが起こっている．Fig.2 は室温で延伸したフィルムの拡 大写真であるが，ネッキングが起こったところで延伸を止め，

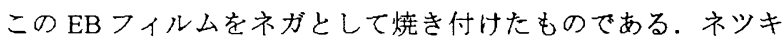
ングが起こるとフィルムが白濁する。これ任延伸によって内部 にミクロな空隙ができ，光の散乱によるものである. $40{ }^{\circ} \mathrm{C}$ 以 下のネッキングはこの白濁した部分の境界線が明確に観察でき
る. TD の延伸では目視による観察から 1 番弱いところの 1 ヶ 所に店力が集中し，延伸方向に対して直角 (MD 方向)にネッ キングの境界線が現れ，そこから延伸が進行する。この方向の 延伸機構は摆尾"，小林 ${ }^{21}$ が提案しているような unfoldingに よるネッキングが起こっている (Fig.2（b ))。この現象は TD のS-S 曲線に対応している。しかし， $60^{\circ} \mathrm{C}$ 以上ではいたると ころでネッキングが発生している゙ ${ }^{3)}$ 。一方，MDの延伸では $40{ }^{\circ} \mathrm{C}$ 以下においてもあらゆる場所で部分ネッキングが次から 次へと起こり，試料全体に渡っているため滑らかな S-S 曲線と なっているが，目視による観察および走查型電子顕微鏡観察 ${ }^{4}$ から unfolding を伴ったネッキング延伸であることが分かった. ネッキングの境界線は約 $\pm 60^{\circ}$ の方向に交差して現れる (Fig.2 ( a )).これはラメラのたわみ, スリップ, 回転によるもので ある。このことは S-S 曲線で, 初期弾性率が MDの方が低い 值を示していることに対応している.さらに，延伸するとラメ ラの長軸が延伸方向に向き TD と同様に unfolding によるネッ キングが発生する. $-196{ }^{\circ} \mathrm{C}$ の延伸は. これらと異なって両試 料とも延伸方向に対して直角に白濁線が入り, 初期弾性率は等 しく Tg 以下にもかかわらず多少延伸されて切断する.

\section{4. 結 $\overline{\overline{2}}$}

我々は HD-PEの EB フィルムの延伸方向によって異なる特 徵的な S-S 曲線の解析を構造的な観点から明らかにした。すな わち，TDの延伸ではラメラの成長方向であり，この方向の延 伸は 1 ヶ所から順次に容易に unfolding が起こる.MDではラ メラの中心部分および両側からラメラが成長して互いに貫入し た部分が成形方向に長く慗がっている．また，ラメラ間も tie chain およびlink fibril ${ }^{5)}$ で結ばれている．それ故，MDの延伸 では, 試料全体に応力が措かり，我々が提案した延伸機構 ${ }^{4)}$ よってラメラの回転を伴った unfolding によるミクロネッキン グが起こって延伸される．これらの延伸方向による構造変化は S-S 曲線と対応している.

最後に, 1960 年代の後半，ネッキングは unfoldingによるか, 部分融解によるものかについて活発な議論があった。 今でも一 部では融解説が信じられているが，この研究の S-S 曲線の形状 と構造の観察 (ネッキングによる白化を含めて)からは unfolding 説が支持されることを付記しておく.

\section{文 献}

1) M.Horio, in 'Proc. 4th Intern. Cong. Rheol., Brown Univ., Rhode Island, (1963)' Part 1, Ed. by E.H.Lee and A.L.Copley, Interscience, New York, p.29

2) K.Kobayashi, in 'Polymer Single Crystals' Ed. by P.H.Geil, (1963), Interscience, New York, p.478

3）村上昌三,粅谷信三,島村 蒸, SEN-I GAKKAI, Prepr., G-23 (1997)

4) 村上昌三,棏谷信三, 島村 蒸, Polym. Prepr., Jpn., 45, 2807 (1996)

5) H.D.Keith, F.J.Padden,JR., R.G.Vadimsky, J. Appl. Phys., 37, 4027(1966) 